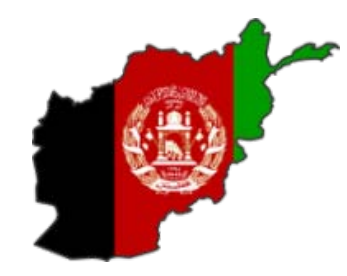

Independent Joint Anti-Corruption Monitoring and Evaluation Committee

\title{
VCA Report on the Process of Land Distribution for Repatriations and Displaced People
}

(Translated from Dari)

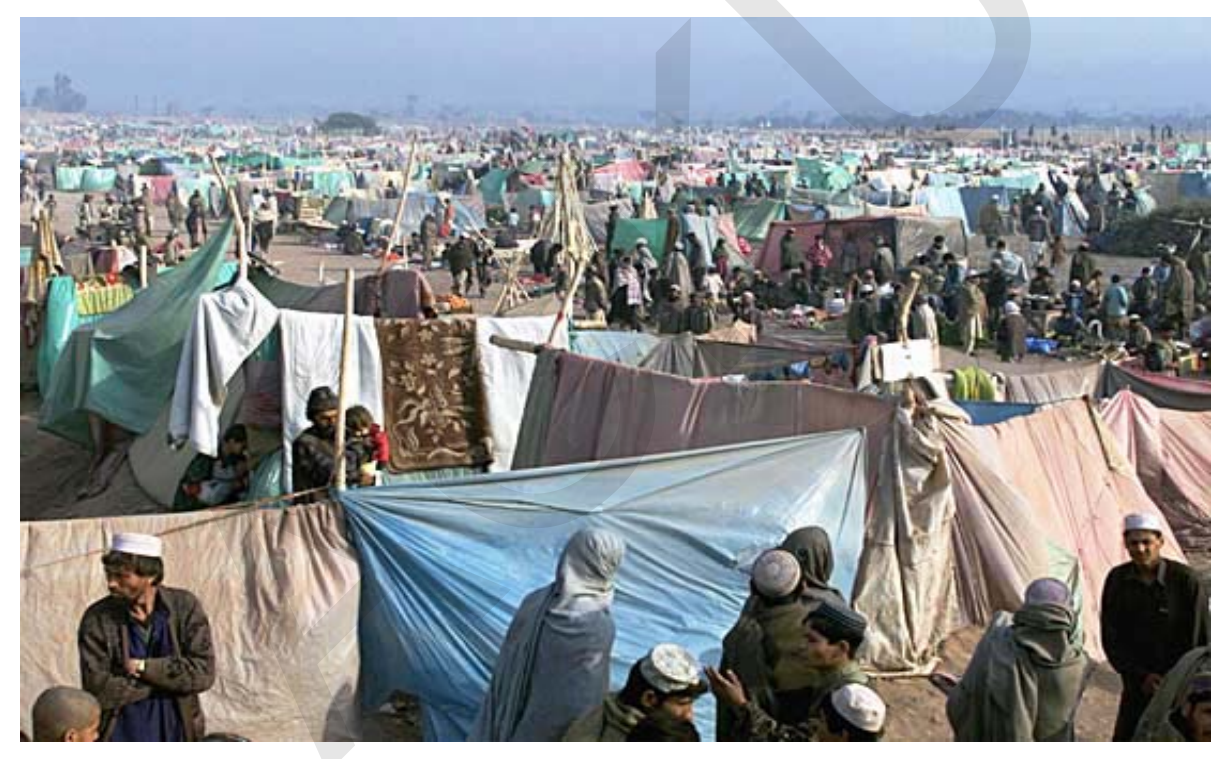

Kabul

October 2013 


\section{Acronyms}

CCLD Central Commission for Land Distribution

ID Identity Card (Tazkira)

IDLG Independent Directorate of Local Governance

MAIL Ministry of Agriculture, Irrigation and Livestock

MEC Independent Joint Anti-Corruption Monitoring and Evaluation Committee

MoE Ministry of Education

MoHRA Ministry of Hajj and Religious Affairs

Mol Ministry of Interior

MoPH Ministry of Public Health

MoRR Ministry of Refugees and Repatriations

MRRD Ministry of Rural Rehabilitation and Development

MoUD Ministry of Urban Development

MP $\quad$ Member of Parliament

MSI Management Systems International

P \& G Pay and Grading

UNHCR United Nations High Commission for Refugees

USAID United States Agency for International Development

VCA Vulnerability to Corruption Assessment

VRF Voluntary Returnees Form (given by UNHCR to refugees upon their return to homeland)

\section{Contents}


Acronyms 2

Contents 3

VCA Objective 5

Introduction to MEC $\quad 6$

i. The Committee 6

ii. MEC Secretariat 6

iii. The VCA Unit 6

I. Report Summary 7

$\begin{array}{ll}\text { i. Context } & 7\end{array}$

$\begin{array}{ll}\text { ii. Findings } & 7\end{array}$

$\begin{array}{ll}\text { iii. Vulnerabilities to corruption } & 8\end{array}$

iv. Recommendations to address vulnerabilities 9

$\begin{array}{lr}\text { II. Preface } & 9\end{array}$

i. Entities involved in the shelter distribution process 9

ii. The need for a VCA 9

iii. Areas covered by the VCA 10

$\begin{array}{ll}\text { iv. VCA Methodology } & 10\end{array}$

III. Assessment of the Legal Framework and Legislative 11

Documents Related to the Process

i. Interviewees' perspective of the legal framework 11

ii. The existence of legislative documents 12

iii. Sufficiency of the legal framework 13

iv. Personal decisions in the process 14

v. Execution of the legal framework 15

vi. Enforcement of the legal framework 16

vii. Vulnerabilities related to the legal framework 17

viii. Recommendations $\quad 18$

IV. Organizational Structure and Human Resources Related to the 18 Land Distribution Process

i. Interviewees' perspective of the human resources structure 19

ii. Sufficiency of human resources 19

iii. Knowledge and experience of staff 20

iv. Presence of terms of reference for staff 20

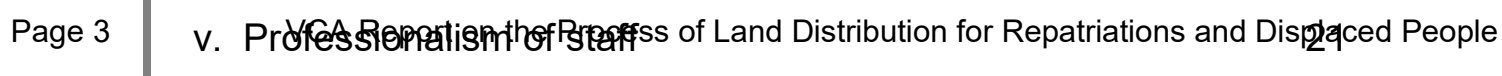
vi. Staff engagement 
vii. Sincerity of staff 22

viii. Vulnerabilities related to human resources 23

ix. Recommendations 23

V. De Facto Practices in the Land Distribution Process 25

i. Stages in the land distribution process 25

ii. Interviewees' comments 26

iii. Personal activities of staff 26

iv. Management and control of staff performance 27

v. Informal assignment of privileges and responsibilities 28

vi. Undue influence and improper direction 29

vii. Improper variation of the process 29

viii. Gifts $\quad 30$

ix. Staff awareness of corruption 31

x. Job security 31

xi. Conflicts of interest 32

xii. Vulnerabilities to corruption $\quad 32$

xiii. Recommendations 33

VI. Information Management in the Land Distribution Process 34

i. Current practices 34

ii. The existence of a system for information management $\quad 35$

iii. Time intensiveness of the system 36

iv. Information security $\quad 37$

v. Vulnerabilities to corruption 37

$\begin{array}{ll}\text { vi. Recommendations } & 37\end{array}$

$\begin{array}{ll}\text { Annex } & 38\end{array}$ 


\section{The VCA objective}

The purpose of conducting VCA on the land distribution process is to identify forms, sources, implications, extent of corruption and vulnerabilities to administrative corruption; present appropriate recommendations in order to improve and speed up the working process; and protect the process from potential vulnerabilities to administrative corruption.

\section{Introduction to MEC}

\section{i. The Committee}


As suggested by its name, MEC is an independent joint Afghan/international committee. The Committee was established based on the Presidential Decree 61 (March 18, 2010) after the need to monitor efforts to fight corruption was identified. The Committee is composed of six reputable experts, three of whom are Afghan and three who are international. National members of the Committee are appointed by the President of Afghanistan and the three international members are proposed by the international community.

The purpose behind the establishment of MEC is to oversee the Afghan government and international community's performance in the fight against corruption independently and in a precise manner. Additionally, the Committee is responsible for developing recommendations and benchmarks directed to national and international institutions and to monitor their implementation. The Committee prepares reports on the progress of the benchmarks and its activities every six months and presents it to the President, the National Assembly, the Afghan public and international community. Likewise, the independence of MEC has been recognized as an irrefutable principle by the Afghan government and international community that has provided the Committee with power to conduct its work effectively.

\section{ii. MEC Secretariat}

MEC is supported by a technical secretariat comprised of national and international staff. The Secretariat is led by an Executive Director and is divided into three main pillars (Governance, Prevention, and Law Enforcement) consisting of an international expert, a national advisor, and a national officer, with over-arching policy expertise provided by a Senior Policy Advisor. The Secretariat works closely with the parties implicated by the recommendations and benchmarks to ensure that they are implemented. The Secretariat also consists of a VCA Unit responsible for undertaking the VCAs.

\section{iii. The VCA Unit}

Part of MEC's mandate is to provide recommendations to institutions to improve their working procedures and processes in providing public services. This objective requires precise identification of vulnerabilities to public services and other agencies' functioning procedures. In 2012, MEC, in partnership with MSI, established a VCA Unit within the MEC Secretariat to conduct VCAs covering a variety of public service areas.

VCAs are a mechanism used to identify susceptibilities to corruption in government processes and develop strategies to reduce the vulnerabilities. The VCA Unit began operations in September 2012.

\section{Report Summary}

\section{i. Context}


Due to the many years of internal war, Afghanistan has a significantly high rate of migration. After the collapse of the Taliban regime in 2001 and establishment of the interim administration, the head of the interim administration issued a decree on refugees' dignified return to country.

In 2005, the President of Afghanistan issued a decree to allocate housing to deserving returnees. Based on that, MoRR and other ministries and institutions were assigned to distribute shelters to deserving refugees. In addition to MoRR, which plays the key role as the original implementing entity in this process, Mol, MRRD, MoPH, MoE, and MoD, the Kabul Municipality at the central level, and sub-national governments (Provinces) are also involved in different roles. Therefore, every working stage of this process is not only time consuming, but also causes serious challenges that requires the involvement of relevant ministries and institutions.

In addition to the fact that the returnees are deserving Afghans who have been victims of incidents related to war for the last three decades and are currently dealing with serious challenges to obtain a piece of shelter through this process of shelter distribution, the first strategic priority for MoRR is to resolve the problem of the lack of shelter for deserving repatriates. To date, the Ministry has distributed more than 54,782 pieces of shelter within 62 residential towns throughout the country and intends to distribute and provide around 500,000 residential shelters in more than 100 residential towns to deserving repatriates.

\section{ii. Findings}

According to the findings of this report, the current probable average amount of bribes being given to employees of this ministry and the respective provincial directorates by deserving repatriates for every piece of land is hundreds of dollars. Therefore, an assessment of this process was of high importance and MEC prioritized a VCA of this process.

Since the specific objective of the VCA Unit is to identify vulnerable issues to corruption, it has not limited itself to individually observe a specific research method and has exploited many research methods when and where needed.

The VCA Unit, after a preliminary assessment that included consultations with high-ranking employees involved in the process and the Ministry responsible for coordinating and implementing the land distribution process as well as a brief study and analysis of the work process, prepared a concise and technical plan of the VCA in order to identify vulnerabilities to corruption in the following four areas:

- Legal and administrative framework

- Structure and human resources

- De Facto practices

- Information and filing management system

The VCA Unit in cooperation with officials of the assigned departments has attempted to collect studies and analyze all existing and functional legal and procedural documents related to the land distribution process. The legal documents provided to the VCA Unit included legislative decree \#279 (June 3, 2002) issued by the head of the Transitional Government, legislative decree \#104 (December 6, 2005) issued by the President of Afghanistan, the Afghanistan National Development Strategy for the dignified return of Afghan refugees from different 
countries of the world, article (6) of resolution \#16 of the Council of Ministers (August 21, 2006) and meeting minutes that have been approved by MoRR.

To identify points vulnerable to corruption, in addition to the collection of information through a variety of methods, the VCA Team conducted interviews with 20 employees and applicants (clients) of this process in different levels.

Considering the extent of corruption in some governmental institutions of Afghanistan, the identification of vulnerabilities does not necessarily require a VCA as a tool. It is not an exaggeration that a person will confront visible corruption at public service institutions when trying to resolve a problem. Surprisingly, even in the presence of the VCA Unit, a variety of corrupt practices were observed within the department being assessed, especially the section appointed to land distribution process. There were also circumstances where colleagues observed apparent bribery, taking presents in the form of tips (Shereni/Bakhshish), negligence in duty, falsification of documents, lack of observing administrative conduct regulations, racial and ethnic discrimination, refusing and denying obligations without legal grounds, and the abuse of job discretion.

\section{iii. Vulnerabilities to corruption}

Generally, responses to questionnaires by employees and clients and information obtained from other sources demonstrate the depth of the problem. Officials of the department have called the situation disastrous. The processing of cases of deserving repatriates who have tried for one to eight years without getting any results in their cases, distributing one piece of land to more than one person, pressure on deserving persons receiving lands to award the building contracts of residential towns to companies belonging to middle ranking employees of the ministry and provincial directorates of refugees affairs, illegal issuance of ownership documents before stipulated timelines, bribes, interference of MPs, ministers and influential deputy ministers in refugee affairs directorates in order to influence the land distribution process, and interference of individuals related to land mafias within residential towns are some of the main issues that have not only made the process vulnerable to corruption, but have made it full of corruption.

On the other hand, legal and structural challenges identified through responses of interviewees indicates the further depth of disaster in this process, which includes a weak legal framework, a lack of a written procedure, low capacity of employees, a lack of required equipment and working tools, Insufficient wages, lack of punctuality, long-term absences, interference of officials, a lack of control over performance, illegitimate, complicated and meaningless bureaucracy, a lack of professional, committed and honest personnel, staff members of the process spending their time on unofficial affairs, political activities of the land distribution commission, a scattered information management system, a lack of transparent follow-up and performance management for staff and a lack of guidance for clients, are all issues that have been detected and identified from the interviewees, VCA Unit observations, studies and analysis of the legal and procedural documents as well as exclusive interviews with officials of this institution.

\section{iv. Recommendations to address vulnerabilities}


The recommendations provided in this report are focused on the development of policies, procedures, and regulations at the ministerial level regarding the land distribution process, the appraisal of employees and identification of competent and professional individuals, recruitment based on competency, development and implementation of training programs for the purposes of employee capacity building, the fair distribution of rights and salaries to staff members of the process, the development of a monitoring mechanism for the land distribution process, the simplification of the working procedure of the land distribution process, improving the current archive system, digitizing documents and the information management system and most importantly establishing a one-stop-shop system for the purposes of improving service delivery and communication between staff members and clients.

\section{Preface}

\section{i. Entities involved in the shelter distribution process}

In 2005 the President of Afghanistan issued decree 104 that assigned MoRR and other relevant institutions to distribute shelters to deserving repatriates. The issue of distributing shelters to repatriates and the displaced requires a proper process. According to the decree, it included the identification of sterile and arid lands, transfer of their proprietary ownership to MoRR by MAIL, development of a map for residential towns by MoUD in coordination with local governments and municipalities and preparations by MRRD, MoEW, MoE, and MoPH for the provision of security, water supply, development, energy, education and health services. Therefore, in addition to MoRR, the other mentioned entities also have a fundamental role in the implementation of decree \#104.

Consequently, there is no doubt that every working stage of this process is not only time consuming, but also causes serious challenges in every field that requires the involvement of the relevant ministries and institutions.

In addition to the Central Settlement Directorate of MoRR, the VCA Unit has assessed the Directorate of Refugee Affairs in terms of their organizational and human resources structure, the actual performance of the land distribution process, and the document and information management system. The objective was to assess the process not the Directorate; therefore, the findings and the presented recommendations in this field are specifically for the land distribution process.

\section{ii. The need for a VCA}

In addition to the fact that all the clients are deserving Afghans who have been victims of warrelated incidents for the last three decades and are currently dealing with serious challenges to obtain a piece of shelter through this process of shelter distribution, the first strategic priority for MoRR is to resolve the problem of the lack of shelter for deserving repatriates. To date, the Ministry has distributed more than 54,782 pieces of shelter within 62 residential towns throughout the country and intends to distribute and provide around 500,000 pieces of residential shelters in more than 100 residential towns to deserving repatriates across the country. 
According to the findings of this report, the current probable average amount of bribe being given to employees of MoRR/provincial directorate from deserving repatriates for every piece of land is hundreds of dollars. Therefore, an assessment of this process was of high importance and MEC prioritized conducting a VCA.

\section{iii. Areas covered by the VCA}

The VCA Unit, after a preliminary assessment and brief study and analysis of the work process, prepared a concise and technical plan of the VCA to identify vulnerabilities to corruption which includes the following four areas:

- Legal and administrative framework of the process;

- Structure and human resources of the process;

- Actual performance of the process; and

- Document and information management system of the process.

\section{iv. VCA methodology}

\section{a. Data Collection}

Since the specific objective of the VCA Unit is to recognize and identify corruption vulnerabilities, it hasn't limited itself to individually observe a specific research method but to reach their goal through many research methods when and where needed.

The VCA Unit has used the following resources and methods to collect information to identify vulnerabilities to corruption:

- General media studies using the desk research method;

- Open discussions with key officials and individuals involved in the process;

- Study and analysis of legal and procedural documents of the process;

- Exclusive interviews with 20 people, both beneficiaries and service providers of the process;

- Conducting focus group meetings; and

- Daily observations of the team members.

\section{b. Identification methods of vulnerabilities}

The identification of vulnerability to corruption processes is based on the contents of article (3) of the Anti-Corruption Law. Article (3) considers the following as corruption: Bribery, embezzlement, stealing documents, wastage of official records, transgressing the legal scope of authorities, misuse of duty, hampering the process or disrupting law enforcement, using governmental facilities and official time for personal affairs, refusing to perform duties without a legal justification, concealing truth, illegal increase of assets, forging documents, pretending to have the power to do an act outside the scope of official power, receiving gifts, negligence, lack of observation of relevant organization's regulations, involving ethnic, regional, religious, linguistic, partisan, gender and personal considerations in performing assigned duties, and to perform or refuse to perform other acts stipulated under the Anti-Corruption Law. 


\section{c. Method of providing recommendations}

Often, solutions come into existence naturally to remove vulnerabilities to corruption. Recommendations in this regard must be entirely meaningful and free of ambiguity and contain substantive managerial and implementing approaches.

\section{d. Method of ordering and arranging main titles of the report}

This report is prepared and organized based on the contents of the questionnaire. The questionnaire has been discussed with 20 people and is comprised of four sections and every section contains a minimum of 5 questions. In this report, those four sections are the main titles and its questions are sub-titles. The rest of the collected information from different sources was considered in the analysis and assessment and also in identifying the vulnerable points to corruption (in some parts without mentioning the source).

\section{Assessment of the Legal Framework and Legislative Documents Related to the Process}

The legal framework of a process includes all legal and procedural documents such as laws, regulations, legislative decrees, resolutions of the Council of Ministers, ministry-approved procedures, and policies - the observation of which are obligatory for the assigned institution in working on the process.

The existence of a regular and accountable legal framework within a specific working area may be primarily used as a good guide for the implementation and practice of the process. Additionally, it is considered as the most important precaution and obstacle against corruption. Often, a common weakness originated from an article or even a word within the legal framework may result in ambiguities and contradictions that can institutionalize corruption within the working processes. Based on these considerations, legislators are bound to consider different aspects of each word's possible meanings and to avoid having ambiguities exploited.

Lawyers develop articles of legal documents having in view the importance of the subject and understanding of mentioned aspects, yet the passage of time, changes in the administration and methods for the implementation of the legal framework, low capacity and misunderstanding of legal documents and other internal and external factors, can make the legal framework vulnerable. Since most of the mentioned factors are expected within the land distribution process, the VCA Unit in addition to assessing other aspects of this process has taken the legal framework under assessment.

\section{i. Interviewees' perspective of the legal framework}

Five questions were asked about the legal and administrative framework of the land distribution process. The answers to these questions clarify various parts of the legal and administrative framework of the process. A summary of the answers given by interviewees is reflected in the following chart. 


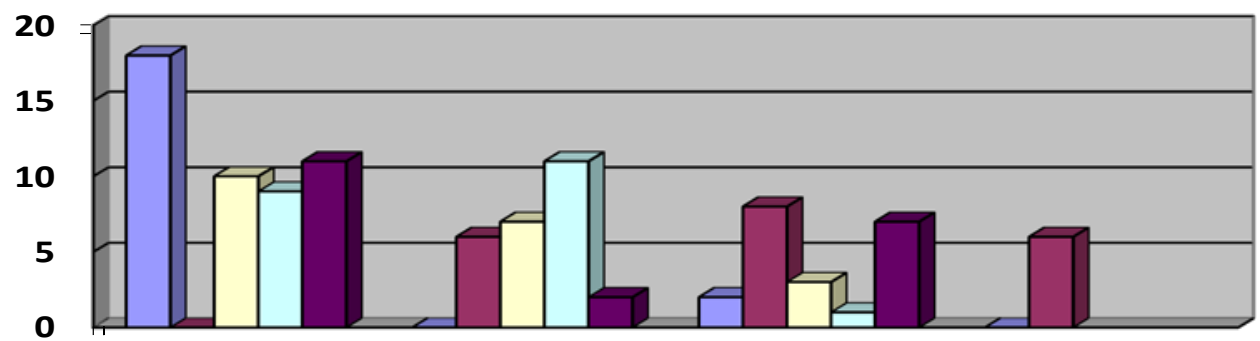

Figure1: Responses to questions $A / 1$ to $A / 5$

\section{ii. The existence of legislative documents}

The VCA Unit in cooperation with officials of the assigned departments has attempted to study and analyze all existing and functional legal and procedural documents related to the land distribution process.

The legal documents provided to the VCA Unit by staff members and officials of the mentioned ministry related to the land distribution process included legislative decree \#297 (June 3, 202) 2 issued by the head of the interim administration, legislative decree \#104 (December 6, 2005) issued by the President of Afghanistan, the Afghanistan National Development Strategy on the dignified return of Afghan refugees from different countries of the world, article (6) of resolution \#16 of the Council of Ministers (August 21, 2006) and meeting minutes that were approved by MoRR.

The findings and analysis of the VCA Unit indicate that only the first part of article \#6 of the mentioned resolution has approved the price of land for each Beswa $\left(100 \mathrm{~m}^{2}\right)$ to be $1500 \mathrm{AFS}$.

The Afghanistan National Development Strategy assigns MoRR the responsibility to manage the dignified return of Afghan migrants from different countries of the world to their homeland, but this document has expired and holds no applicability. Still, whatever is quoted from the strategy about the land distribution process or eliminating the problem of lacking shelters by MoRR is considered a priority.

Decree \#297 (June 3, 2002) issued by the head of the interim administration is an indicator of the readiness of the Afghan government to welcome the return of Afghan refugees to their homeland cannot be used as a guide in this process.

The document related to the capacity building seminar conducted on 13-14 September 2009 and signed by the Minister of MoRR reflects the challenges and prompt decisions of provincial directorates in general and contains just one article concerning land distribution. The subject reflected under this article of the mentioned document regarding the distribution of residential pieces of land to refugees within the refugees' residential towns does not include anything new and only emphasizes making decree \#104 of the government the procedural base of conduct.

Therefore, the only valid legislative document for the legal framework for the land distribution process is decree \#104 (December 6, 2005) of the Afghan government which is subject of the assessment of the process. 
The first article of Presidential Decree \#104 states the following: "This decree is ordained based on resolution \#30 dated 07 November 2005 of the Council of Ministers for the purposes of distributing arid and sterile governmental lands in order to resolve the problem with the lack of shelters for deserving repatriates and internally displaced people."

The decree includes 17 articles that are aimed at covering all aspects of the land distribution process including shelter for repatriating refugees and internally displaced people as well as the duties and obligations of the land distribution commission both in the capital and provinces and ministries cooperating in the land distribution process.

\section{iii. Sufficiency of the legal framework}

In their comments the interviewees focused on the necessity and vagueness of a provision of the procedure and a single description of Presidential Decree 104. Some of the interviewees emphasized the need for drawing up a proper procedure for this reason. They did not think the decree was enough to address all the legal needs of the land distribution process.

Respondents who claimed that the decree was clear and free of problems emphasized that the decree had no pitfalls and all of its contents were related to the land distribution process. They believed that problems that occur during the process were because of a lack of procedures and internal guidelines, which was easily observable. According to this group of respondents, decrees issued for any purpose are general, but there is a need for the preparation of proper internal regulations and procedures for employees. For the time being, unfortunately, there is no such a measure in place for the preparation of such procedures or regulations.

Meanwhile, respondents who agreed with the question believed that Presidential Decree 104 had a number of pitfalls and many of its articles were inconsistent, defective, vague and uneven, paving the way for corruption in the land distribution process. Specifically, one of the pitfalls indicated by interviewees is vagueness and inconsistency in some terms used in the decree. One of the terms used is 'valid documents' which can be found in article two of the decree. This term has not been defined and therefore, it can be misused and facilitate corruption. Article 2, sub-article 1 (b) of the decree sets the following condition for being identified as an eligible repatriate:

(b). Possesses a Voluntary Repatriation Form (VRF) or other valid documents that confirm his/her return to the country or from internal displacement to the area of origin and permanent residence.

From the respondents' point of view, the pitfalls and shortcomings in the decree are not limited to the above mentioned sub-article. They believe that sub-article 3 of article 2 in the decree has a more serious deficiency. Based on this sub-article, only those who do not have any land in their name or in the name of their spouses or children are eligible for the process. According to the respondents, the concerned commission has identified many people as eligible for land allocation, despite having land in their name in various parts of Afghanistan that are either not usable or have other kinds of problems. More importantly, whether a repatriate or an internally displaced person has land in his name in Afghanistan cannot be verified as there is no database or other system in the concerned organization for this purpose. 
At present, the Directorate of Refugees' Affairs delegates its responsibilities by handing a letter to the eligible repatriate in which it asks the representative of the district where the repatriate resides to verify whether the repatriate has any land in his name or not. Such a measure only paves the way for corruption and adds to the illegal income of tribal elders and district representatives.

Also, having a VRF or other valid document on hand does not necessarily mean one is eligible for the land distribution process. There are a number of cases of people who continuously travel between Afghanistan and Peshawar, Quetta, Mashhad or Zahidan to obtain money set aside for repatriates and receive the required documents from UNHCR. In contrary, real refugees who have returned to Afghanistan without registering with UNHCR, but are actually eligible for land, remain deprived of their right just because they do not possess a 'valid document' - VRF which has varying definitions to the government officials.

Issues related to the Tazkira (Afghan national identity card) have also led to many problems. In a country where no proper data on its population exists and where no proper system for checking the identity of its people is present, verifying the status of repatriates who have migrated without obtaining a tazkira or have been born outside of the country is a difficult task. Obtaining a tazkira, with a readable stamp on it is easy by bribing the concerned employees and in such a way anyone can claim eligibility for the land distribution process. This trend has resulted in a prolonged procedure and for more corruption.

Another problem is the verification of whether a repatriate has land in his name or in the name of his spouse or children. Suppose a person repatriates after being away from his country for years and has land in a remote district of Afghanistan. His land is of no use to him because it is located in a far, insecure, deserted or mountainous area where having a sustainable livelihood is difficult for him. How can he be deprived of his right of being identified eligible for the process of land allocation? The issue of his wife and children is also against the rules of personal civil rights especially when a woman's right is used without her prior consent.

From all the findings and responses by interviewees, a conclusion can be drawn that Presidential Decree 104, when applied in certain cases, is a general, vague, defective and impractical document which is not based on the realities. For the successful implementation of the decree, there is a need for the preparation of proper internal procedures, rules and guidelines. The absence of internal procedures, rules and guidelines has caused the decree to remain vague for the concerned employees. Implementation of the decree faces challenges and has led to corruption. Therefore, in general, conditions set in article 2 of the decree are considered to be contributing to corruption in the concerned organizations.

\section{iv. Personal decisions in the process}

Opinions expressed regarding this question favored respondents who thought the chances for personal decisions existed in the process. According to them, the interpretation of the law varies from person to person and no standards exist except that the concerned employees decide for themselves to accept or reject applications based on an article from the decree. Those who believed that there is no chance for the use of personal decisions in the legal framework accepted the decree as a complete and clear document. 
Before referring to the opinions and answers from the interviewees, it is necessary to specify the meaning of 'personal decision'. Personal decisions mean that in some cases, due to pitfalls in the law, the employees of the organization are compelled to make decisions on their own or intentionally execute a task without considering the contents of the law. The question on whether Presidential Decree 104 paves the way for personal decisions has been asked from the interviewees. A majority of the respondents have given a positive answer to this question.

In their opinion, the legal documents provide opportunities for the use of personal decisions. One of the interviewees answered in the following words: "I do not know about the law, but employees who are tasked for the process of the distribution of land treat the people in a way that one doubts if any laws or regulations exist in this organization. They do not consider the problems and conditions being faced by the people and make decisions according to their wishes."

Some other respondents, who also work as employees of the land distribution process, say "certain factors like vagueness in some parts of the decree, differences in the level of knowledge and capacity of the employees and the presence of problems in their job descriptions paves the way for personal decisions." Nonetheless, these personal decisions do not actually lead to corruption or harm the process. According to them, employees working for the land distribution process make decisions based on their judgment of a case just for the purpose of resolving the problems of the applicants and such a step has no harm or disadvantage to the client. However, they do not consider such personal decisions as complete and safe. They fear that such decisions, whether taken due to legal flaws or intentionally could turn into a culture in an organization, as can already be observed in some cases. The respondents believe that there are employees who do not give any importance or respect to the laws and regulations and act freely according to their own desires and without any fear or concern.

From responses and information gathered from interviewees it can be concluded that personal decisions whether taken because of legal flaws or intentionally have a fundamental role in mismanagement and disorder in the land distribution process. In other words, personal decisions by concerned employees in the process have made it seriously fragile and such fragility can be considered a cause that could lead to corruption.

\section{v. Execution of the legal framework}

Respondents who said that laws were not implemented and obeyed appeared extremely dissatisfied and expressed concerns over the lack of a team to oversee the activities of the directorate. Nonetheless, respondents who had enough information about the process and were indeed the employees of this directorate described the situation as good and seemed satisfied with it.

The successful implementation of legal documents, especially Presidential Decree 104, is related to various factors, some of which have already been discussed while others are mentioned in the following pages. Briefly, as stated above, the vagueness of the decree and problems in the job descriptions of concerned employees and the personal decisions they make can be deemed as some major obstacles for the proper and successful implementation of the land distribution process. 
Our findings from the responses to the question, "Are legal documents including Presidential Decree 104 implemented successfully in the process?" is that legal documents related to this process are not implemented in a proper manner that leads to the satisfaction of the applicants. The majority of the interviewees, in response to this question, said that if the decree or other legal documents were implemented even partially, the people would not have so many complaints. According to them, the legal documents including Presidential Decree 104 are not efficiently implemented because the concerned employees demand gifts, delay tasks, do not take interest in their jobs, arrive late to their offices, remain unnecessarily absent and behave rudely with the applicants.

In response to the above question, one of the interviewees said, "The time when $20 \%$ of laws and regulations could be implemented in the organization, the level of problems will not remain as it is today." The respondents emphasized that the applicants cannot share their problems and demands with the Directorate of Refugees Affairs. In some cases, the applicants have even witnessed physical violence from some officials of the directorate. The interviewees believe that not only the decree and other legal documents are not implemented properly, but also the concerned employees try to pave the way for corruption. From their point of view, most of the deserving repatriates are fed up, because of the lack of competence and effectiveness of this organization and regret submitting their applications there.

Keeping in view the information and responses obtained from the interviewees, it can be concluded that Presidential Decree 104 and instructions of the Council of Ministers and the Minister of Refugees and Repatriations Affairs and other legal documents related to the land distribution process are not implemented in a proper manner. Therefore, shortcomings in the process have resulted in the dissatisfaction of the people and lowered their trust in the organization. At the same time, such shortcomings have also made the land distribution process vulnerable to corruption.

\section{vi. Enforcement of the legal framework}

Opinions expressed in response to this question by interviewees were that punishment laws exist and they emphasized that government employees have clear responsibilities in light of the Civil Service Law of Afghanistan. Breaking any content of this law is considered a crime, for which giving a warning notice is the first option. Based on sub-article 2 of article 11 of Presidential Decree 104, the concerned officials can also send cases of repatriates who commit fraud and misrepresentation to the Attorney General's Office. However, respondents with negative answers emphasized the fact that the laws are not implemented. According to them, such a thing has not yet happened because the implementation of legal documents has always been compromised which has paved the way for corruption.

Inclusion of penalties in laws and other legal documents is one of the factors that greatly help in their implementation. Whether the legal documents that pertain to the land distribution process include any penalty for employees who do not obey them or do not implement them effectively is a question to which most of the interviewees gave negative responses.

The interviewees say that no punishment has been included in the decree and other legal documents. Nonetheless, those employees, who do not implement legal documents related to the process, can be prosecuted according to other laws of the country including the Civil 
Servant Law. According to them, including such laws in the decree is not necessary because they have already been discussed in the criminal laws of the country and the Civil Servant Law.

Presidential Decree 104 contains an article based on which MoRR can refer cases of a repatriate who acts against the contents of the decree to judicial authorities. Article 11 subarticle 2 of the decree states:

"If it is proved that a beneficiary under Para (1) of this article has received a plot of land in contradiction to the provisions of this Decree, the land will be repossessed, distributed to another beneficiary, and the individual will be prosecuted."

From the responses of the interviewees, it can be concluded that certain penalties in Afghan laws specifically in the criminal laws and Civil Servant Law have been included. The related sub-article in Presidential Decree 104 is not only unnecessary but also does not solve any problem. According to the respondents, whenever governmental authorities intend to prosecute the employees who act against the decree and other laws related to the process of the land distribution, they can use the above mentioned two laws without any problem.

\section{vii. Vulnerabilities related to the legal framework}

Findings of the assessment indicate that Presidential Decree 104 is the only legislative document based on which MoRR manages the land distribution process across the country. Vulnerabilities identified within this document after studies and analysis, responses of interviewees to the questionnaire, objective observations of the decree implementation and other sources are as follows:

- Ambiguity of the decree and the lack of any other instructing document for its implementation means that even though the contents of the decree include 17 articles and some of them are general instructions discussing the manner of land distribution, MoRR as the main organ for decree implementation has not developed any procedure that could explicitly apply provisions of the decree. This issue has resulted in a variety of interpretations of the decree, the slowness of its application and also the increase in the instances of abuse, corruption and injustice within the land distribution process.

- Another gap within the legislative documents is the issue regarding the establishment of the central and provincial commissions for the land distribution process. Disregarding the amount of existing coordination among members of commissions, in Kabul it has been particularly challenging between national institutions (e.g. ministries) and secondary units (e.g. Office of the Kabul Governor). This has caused a lack of cooperation between the governor's office with the central commission due to the insistence of the Kabul Governor's Office to have the provincial commission of Kabul led by the deputy governor according to article 7 of the decree and that Kabul local institutions shall be members of the commission which will result in disqualifying central commissions in the land distribution process and on other hand will cause misunderstandings between the mentioned organs. Therefore, article 7 of the decree is not only vulnerable to corruption, but has also become a factor for the lack of coordination and misunderstanding among local and central institutions.

- Another issue is that Presidential Decree 104 is separated from administrative procedures. MoRR has unfortunately been unable to develop and approve an administrative procedure in most of its processes. Therefore, lacking a united procedure 
to run administrative processes has not only resulted in the vulnerability of the land distribution process to corruption, but has also resulted in corruption in other working areas of this ministry.

- Findings of the VCA indicate that a considerable part of the existing scope of corruption within the land distribution process is emerging from the lack of a clear legal framework. Therefore, removing such vulnerabilities requires the establishment of a legal framework within the land distribution process.

\section{viii. Recommendations}

In order to eliminate the vulnerabilities identified above, further guarantee transparency within the land distribution process, ensure justice, handle rights of deserving people, prevent misuses of people and particular parties, and prevent corruption within the process, the recommendations provided below with regards to the legal and administrative framework of the land distribution process are developed as follows:

a. In order to improve the current situation, a comprehensive legal framework in relation to the duties and responsibilities of MoRR, applicable and in accordance with the current situation of Afghanistan should be designed to facilitate the dignified return of repatriates.

- Responsible entity: Central Commission of Land Distribution Process in coordination with involved entities

- Deadline: Within 6 months after the issuance of this report

b. A comprehensive procedure covering all areas of work related to land distribution taking into account the content of the legal framework should be developed and practiced accordingly.

- Responsible entity: Central Commission of Land Distribution Process with involved entities

- Deadline: Within 6 months after the issuance of the report

c. A transparent and applicable mechanism for the purposes of proper monitoring and control over involved institutions in the land distribution process should be developed and practiced.

- Responsible entity: Central Commission of Land Distribution Process in coordination with involved entities

- Deadline: Within 6 months after the issuance of the report

\section{Organizational Structure and Human Resources Related to the Land Distribution Process}

The organizational structure of an entity is a crucial part of a system that is designed with the required instruments and equipment, ability, material and non-material capability, sincerity, commitment and working opportunity for the purpose of undertaking the planned activities, following the organizational goals and obeying the legal framework and working procedures. The efficiency of an organization and human resource structure depends on having efficient, expert, committed, talented and creative human resources, a standard legal framework, strong 
political support, comprehensive strategies and policies, a functional working environment and instruments, proper job descriptions, proper planning, leadership and efficient management.

Therefore, the organizational and human resource structure management is one of the main areas focused on by the VCA Unit. The purpose was not only to identify the weak areas, shortcomings and pitfalls of the organizational and human resource structure and know where corruption could take place but also to recommend measures to improve the structure.

Initial results in this area indicate that in addition to the legal framework, organizational and human resource structures, job descriptions and other working instruments exist for the process of land allocation. However, a lack of strategy and policy, a comprehensive working procedure, strong political support and working plan, in addition to a lack of proper arrangements for leadership and management, have all caused the activities and other tasks performed by the concerned staff of MoRR to be less effective.

\section{i. Interviewees' perspective of the human resources structure}

To find out the degree of vulnerability of this area to corruption, seven questions were asked from 20 individuals out of whom 12 were civil servants (of grade-5) working with concerned departments and the other eight were applicants with applications at various stages of the process, including the initial, middle and final stages. Responses to the questions have been obtained in such a way that a careful analysis based on the opinions of the interviewees, other documents of MoRR and observation of members of the VCA Unit lead us to identify vulnerabilities in this area.

The information, figures and views of the respondents received through the questionnaires have been briefly analyzed below under the title 'the organizational and human resource structure.'

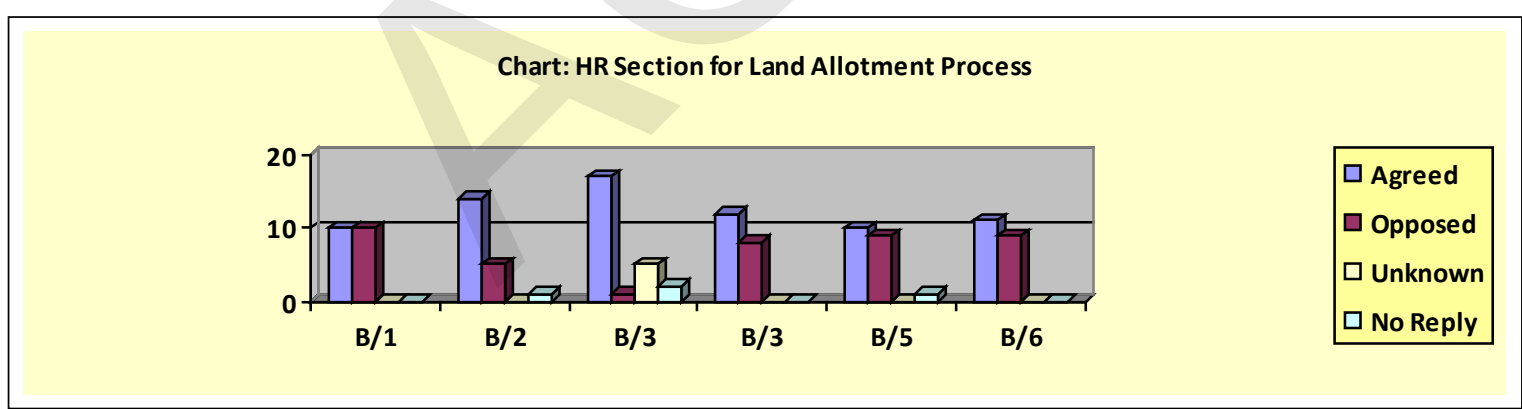

Figure 2: Responses to questions $B / 1$ to $B / 6$

\section{ii. Sufficiency of human resources}

The respondents emphasized that if the concerned employees, whatever their number is, could undertake their duties and responsibilities in accordance with the standards and regulations and reach their office on time and take interest in their jobs, all the work could be done with ease and without delay and the applicants would not face any problems. Unfortunately, the concerned employees do not reach their office on time; they leave the office before the official time and cannot properly manage their activities. Such a trend creates problems both for them and the customers. 
Keeping in view the above mentioned points, the presence of an adequate number of employees plays a crucial role in the development of an organization that has the satisfaction of its customers. Nevertheless, our observation and analysis of this organization and views expressed by interviewees in response to the question "Is the number of employees adequate for effective implementation of this process?" indicate that the organization lacks an adequate number of staff.

In short, from the study and analysis of the information and responses of the interviews, it can be said that the number of staff for the land distribution process is not enough as compared to the workload and the number of visitors of the concerned offices. As mentioned, the organizational structure is defective which can be considered as one of the major challenges in the land distribution process. The problem has negatively impacted the provision of services to the people and has resulted in their dissatisfaction.

\section{iii. Knowledge and experience of staff}

A majority of the interviewees gave positive responses to the above question. According to them, employees working for the land distribution process have varying levels of knowledge. Interviewees say that the level of knowledge possessed by the concerned employees is adequate keeping in view the capacity in the other governmental organizations and the prevailing conditions in the country. Respondents say most of the employees of the process have a bachelor's degree while some of them are high school graduates.

Interviewees who said the concerned employees did not have the required qualification also claimed that some of the employees were not even high school graduates. They believed that if the staff working for the process had enough qualifications, their behavior with the people would be better. In response to the question, one of the interviewees said, "in the Directorate of Refugees Affairs, there are employees who even do not have the basic level of literacy in reading and writing." In the view of most of the respondents, however, the activities that have to be performed in the land distribution process do not necessarily require an employee to have completed his education in a specific field as even high school graduates can easily undertake the related activities.

After studying and analyzing information obtained from interviewees, visits and discussions with them and the overall observation of the VCA Unit, it can be said that the level of qualification and experience of employees of the land distribution process is adequate as compared to other government entities. Nonetheless, it should not be neglected that based on the remarks of some of the interviewees and observations recorded in this regard, employees working for the process lack the required morals and interest. At the same time, they need technical and ethics training.

\section{iv. Presence of terms of reference for staff}

Discussions that took place in this regard were mainly based on the presence of problems, vagueness, and defects and in the coordination in job descriptions and their implementation. Additionally, the last article of the job descriptions that includes, "Other related duties from the officer or supervisor" was also objected to because it has created misunderstandings and ambiguity among employees and is also misused by officials. 
The analysis of the VCA Unit and responses of the interviewees indicate that an absolute majority of the employees working for the land distribution process in the Directorate of Refugees Affairs have job descriptions. They say their job descriptions were prepared after they completed the P\&G process of the Independent Administrative Reform and Civil Service Commission. A few of the employees have not gone through the process and currently do not have any job descriptions. For the question, 'whether the job descriptions of the concerned employees are in accordance with their duties or whether the contents of the job descriptions of these employees have pitfalls,' a majority of the responses indicated that the job descriptions of the concerned employees have pitfalls. Specifically, they are vague, inconsistent, copied and lack coordination and relevancy.

In general, a study and analysis of the collected information and responses from the interviewees indicate that job descriptions of the employees require a serious review. In this way, problems in the job descriptions could be removed and be adjusted in accordance with the post and ranks of the employees.

\section{v. Professionalism of staff}

Most of the discussion came from clients who complained about the rude attitude of the employees. According to them, employees of the directorate did not treat the applicants professionally. They were insulted by employees that sometimes led to physical clashes.

A majority of the interviewees - most of whom were employees of the Directorate of Refugees Affairs of MoRR - said that the concerned employees have not shown professionalism in the implementation of the process. According to them, the employees behave with the people without keeping in view their job descriptions, laws and regulations. On the other hand, a number of people visiting the Directorate of Refugees Affairs for the land distribution process emphasized that if the concerned employees acted in accordance with their job descriptions, laws and regulations, most of the problems of the people would be resolved and complaints would diminish.

After studying all the findings and responses from the interviewees, it can be stated that the behavior of the employees of the Directorate of Refugees Affairs, specifically those working for the land distribution process, is not in accordance with their job descriptions, laws and regulations. People are not only dissatisfied with the attitude of the employees, but also have serious complaints.

\section{vi. Staff engagement}

In the discussion about the question, the interviewees expressed their views about the reasons behind the lack of interest of employees in their jobs. According to them, low pay, lack of penalties and other such issues caused the employees to not take interest in their job. Most of the employees had no other options except working in the concerned office, they said. One of the respondents who is an applicant of the land distribution process said, "employees of the land distribution process not only treat the people unprofessionally, but one can observe bias and nepotism in their attitude."

The interest of employees in performing their duties and responsibilities has a key role. A lack of interest among employees working for the process is one of the factors that has deeply 
impacted the process and has put its successful implementation in doubt. What we found from answers to the question, "do the employees of the land distribution process take interest in undertaking their duties and responsibilities?" is that the concerned employees perform their work without adequate interest. The reasons for their lack of interest, as stated by the interviewees, are a lack of encouragement in government offices and low salary payments. The respondents believe that whenever the concerned employees found any better option, they would abandon their current employment.

Based on the views expressed by the interviewees, the fact that the concerned employees accept gifts and bribery, delay work, remain unnecessarily absent and arrive late to their offices, clearly depicts their lack of interest in their jobs. The interviewees say that if the employees had taken a keen interest in performing their duties and responsibilities, the land distribution process could be implemented quite successfully.

It can be generally concluded from the analysis and study of the collected information and responses of the interviewees that the employees of the land distribution process are not interested in their jobs. Therefore, a lack of interest of the employees in their duties is one of the challenges facing the land distribution process. This has resulted in a vulnerability of the process and dissatisfaction of the people.

\section{vii. Sincerity of staff}

The interviewees believe that it would be unjust to call the employees highly insincere. Nevertheless, we have to admit that many employees have no sincerity in fulfilling their responsibilities and are looking for ways to obtain bribes.

The explanations above clarify the level of sincerity of the employees towards their jobs. Despite that, for further clarification about the subject, it is important to properly define 'sincerity' in this study. Here sincerity means the performance of the employees on the basis of generally accepted moral values. Whether employees of the Directorate of Refugees Affairs, especially employees working for the land distribution process, are sincere, is the question to which a majority of the interviewees expressed negative views.

People interviewed in this study say that all employees working in governmental organizations are not as sincere as they should be. However, the issue appears more serious in the Directorate of Refugees Affairs. A majority of respondents of this question were applicants and employees of the concerned organization. According to the respondents, insincerity of the employees is indicated by the fact that they demand gifts, do not take interest in their jobs, delay works, waste time, arrive late to their offices and accomplish their own personal work during official time. One of the respondents said, "If the employees were sincere, they would not delay work that can be done within a day or week to one full year." The interviewees do not neglect exceptions. According to them, there are people in the directorate who work really sincerely but they are only a few in number.

In short, it can be concluded from all the findings and responses of the interviewees that the employees of the land distribution process lack sincerity in performing their duties. This has resulted in vulnerabilities in the process and the dissatisfaction of the people. 


\section{viii. Vulnerabilities related to human resources}

The findings of the assessment show that MoRR has gone through the P\&G program of the Independent Administrative Reforms and Civil Services Commission about a year ago and has a relatively appropriate strategic program and terms of reference. However, after studies and analysis of the strategic plan and terms of references of some positions within the departments involved in the process, responses of interviewees to the questionnaire, direct observations of the process of decree implementation and other sources, there are vulnerabilities identified in the areas of structure and terms of reference of the process that are as following:

- The General Directorate of Resettlement under MoRR was originally tasked and bound to develop regulations, procedures and mechanisms for the implementation of the strategy of the ministry in the field of distributing shelters to repatriates or deserving displaced people and monitoring the implementation process, but has not taken action as required. The Directorate is affected by a crisis of lacking capacity related to human resources and access to essential facilities in the implementation of the land distribution process.

- MoRR, the Refugees Affairs Directorate of Kabul and other provincial directorates as inferred from the statements of officials of this ministry are suffering from challenges of capacity and the inability to perform duties that has caused all working areas of the ministry both in the capital and provinces to face corruption. Therefore, vulnerability to corruption of the land distribution process has a connection to the overall governing situation within the ministry that has caused the entire working areas of the ministry related to the land distribution process to become vulnerable to corruption.

- In addition to the absence of a standard management mechanism in the process, the lack of professional, talented, honest, committed and capable employees is an issue that has made the existing wound in the process incurable and the process fully vulnerable to corruption.

- Others issues obtained through the assessment interviews indicate unprofessional behavior of high-ranking employees with low-ranking staff members, the misuse of job descriptions, and transfers and unjustifiable appointments. Although the ministry follows the Law of Civil Servants and the regulation of civil servants conduct, according to the statements made by high-ranking officials and staff members of this ministry, there are violations seen in high levels of this ministry that have affected staff members of the land distribution process and caused them get less eager, unwilling to work, less committed and dishonest.

- Although the P\&G program has been implemented by the Independent Administrative

Reform and Civil Service Commission and the structure of the ministry has been generally reviewed and new terms of reference developed with reasonable content, in some departments and also sections related to the land distribution process there are still positions that are vacant and some staff members are working temporarily. The temporary appointment of the staff makes the process vulnerable to corruption.

\section{ix. Recommendations}

Unfortunately MoRR is seriously suffering from capacity-related challenges in terms of human resources and the only solution is to bring changes in key position holders and identify professional individuals committed to the country. They could play the key role in altering the governing manner through developing policies and bringing positive changes to the governing situation through administrative and technical initiatives. This alteration needs some transfers, 
dismissals, new recruitments and retirement within different levels of the mentioned ministry's officials.

a. Qualified new graduates should be recruited and go on top of the ministry's reform priorities particularly in the land distribution process.

- Responsible entity: MoRR in coordination with the Independent Administrative Reform and Civil Service Commission

- Deadline: Continuously after issuance of the report.

b. A comprehensive procedure covering all areas of work related to land distribution taking into account the content of the legal framework should be developed and practiced accordingly. The anti-corruption related institutions should conduct special seminars in order to raise awareness of this ministry's employees particularly those who are working on the land distribution process as soon as possible.

- Responsible entity: High Office of Oversight in coordination with the Ministry

- Deadline: Twice annually after issuance of the report

c. Serious cooperation of the Independent Administrative Reform and Civil Service Commission is required with the ministry in the following four fields:

i. The vacant posts should be filled with qualified, professional, committed and honest people;

ii. The uncommitted, unprofessional and corrupt officials should be identified using the annual appraisal scheme immediately;

iii. Professional training programs should be developed and conducted for employees of the ministry, especially the land distribution department;

iv. Exceptional employees deserving super-scale salaries in the ministry and specifically the qualified employees for super-scale salaries within departments related to the land distribution process should be recognized;

- Responsible entity: MoRR in coordination with the Independent Administrative Reform and Civil Service Commission

- Deadline: 6 months after the issuance of the report

d. The cases and documents of transfers, appointments and terminations of employees in the ministry should be evaluated by an authorized board composed of respective organs and legal institutions in order to identify disqualified people and also violations committed by high-ranking officials in terms of unprofessional conduct and misuse of job discretionary influence in the recruitment processes.

- Responsible entity: High Office of Oversight, Attorney General's Office and the Independent Administrative Reform and Civil Service Commission

- Deadline: 3 months after the issuance of the report 


\section{De Facto Practices in the Land distribution Process}

'De Facto practices' mean the actual performances of staff in the land distribution process, which includes its starting point, challenges, and standards and legal framework. What are the weak points of the process, system or organization that lead to corruption? How have these weak points, that hinder completion of work within a reasonable time, entered the process? And finally, what possible methods can lead the process towards the right direction and what technical recommendations are required for improving and activating a real process for reaching objectives that can be presented to the concerned ministry in a fruitful and effective manner by keeping in view its current condition of material, technical and human resource capacity?

Before mentioning the views of respondents in this regard, the following is what has been obtained in the research in a documented form from the study and analysis of samples pertaining to real activities in the process of land distribution.

\section{i. Stages in the land distribution process}

Steps in the land distribution process given below include all the actual activities and measures that can be seen in a sample dossier provided to the VCA Unit by the Directorate of Refugees Affairs. Below is the process through which a deserving repatriate has to go from the first day that he applies for land until the day he receives temporary ownership documents of land.

Whatever has been reflected in the following process is based on a completed file that has been carefully prepared. It includes papers from the first application written to MoRR for the provision of a shelter in one of the housing schemes in Kabul city to the final temporary ownership document obtained by a repatriate after completing $40 \%$ of the construction work. Therefore, whatever has been reflected in the following table in fact reflects the paperwork done in one year for the purpose of allocating a piece of land to a repatriate and excludes any wrong or fake information.

\begin{tabular}{|c|c|c|c|c|}
\hline $\begin{array}{l}\mathbf{N} \\
\mathbf{O}\end{array}$ & Stages within the Process & 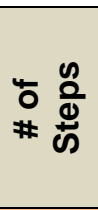 & $\begin{array}{c}\text { Vulnerabili } \\
\text { ty Degree } \\
(5-1) \\
(1=\text { Strong } / \\
5=\text { Weak })\end{array}$ & Remarks \\
\hline 1 & Submission of Application and Identity Check & 15 & 2 & \multirow{5}{*}{$\begin{array}{l}\text { Vulnerability } \\
\text { grading of Stages } \\
\text { in this process } \\
\text { have been graded } \\
\text { based on the } \\
\text { information } \\
\text { reflected in the } \\
\text { questionnaire and } \\
\text { observations of the } \\
\text { assessment team. }\end{array}$} \\
\hline 2 & Proof for repatriation or internal displacement & 14 & 2 & \\
\hline 3 & $\begin{array}{l}\text { Record and register - deserving or non-deserving } \\
\text { applicant by commission }\end{array}$ & 18 & 1 & \\
\hline 4 & $\begin{array}{l}\text { Payment of the price of land and allocation of land } \\
\text { to the deserving repatriate }\end{array}$ & 11 & 2 & \\
\hline 5 & $\begin{array}{l}\text { Complete } 30-40 \% \text { of the construction and receive } \\
\text { the temporary document by the approved applicant }\end{array}$ & 10 & 2 & \\
\hline
\end{tabular}


It is to be noted that based on comments from some middle-ranking officials of the Directorate of Refugees Affairs some changes have been brought in the process. Therefore, currently the steps in the table above may not always reflect the condition faced by the repatriates. According to high authorities of MoRR, the condition continues in the same way and has not undergone any changes.

Based on the documented findings from the above mentioned file as observed in the table, a repatriate has to go through five stages in order to become the temporary owner of the land. Each stage contains a number of steps that require the signature of authorities and civil servants of the concerned organization. A part of this bureaucracy is based on administrative reasoning. However, in many cases, it can be observed that the attitude has been informal and there is no reason behind this except escaping individual responsibility. An applicant has to go through a total of 63 steps of the process in order to be identified as a temporary owner of the land.

\section{ii. Interviewee comments}

In addition to documentation of the process through a completed sample file pertaining to real activities of employees working for the land distribution process, the VCA Unit has also used information from other sources such as special meetings with middle-ranking officials of MoRR and the concerned directorate, interviews with applicants, and practical observation of activities of the concerned employees. This information is evaluated below.

Summary of respondents' views about the questions on actual performances and de facto practices in the process can be observed in the chart attached in the Annex.

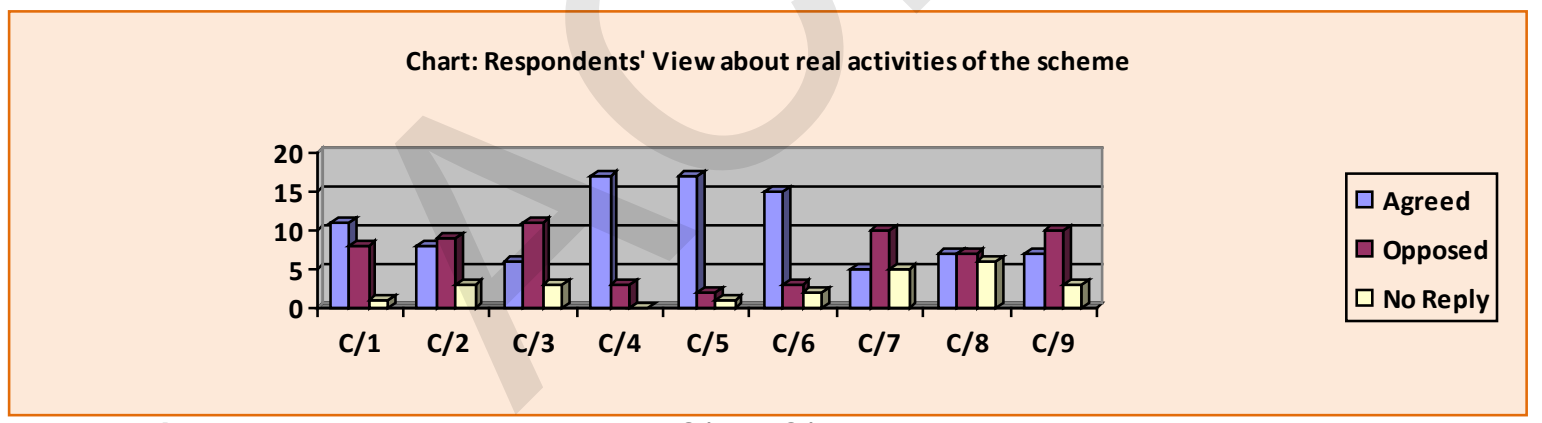

Figure 3: Responses to questions $\mathrm{C} / 1$ to $\mathrm{C} / 9$

\section{iii. Personal activities of staff}

Views expressed in reply to this question by respondents were generally based on their belief that informal activities were undertaken by the concerned employees. They accused some of the employees of having personal companies in the housing schemes which they have made by misusing their status.

Before referring to the responses of the interviewees and information in the questionnaire, it is necessary to shed light on the meaning of 'informal activities' in this research. Informal activities include activities that have not been mentioned in the law and regulations and the employees perform them during the official time which is against the law and regulations. In other words, informal activities can be defined as performing personal activities during official time. The condition in the Directorate of Refugees Affairs and whether informal activities are performed by 
the employees of the land distribution process have been asked from all interviewees in this research.

There are equal negative and positive responses in this section. Half of the respondents have said that in some cases the employees have been observed performing informal activities. They emphasized that the concerned employees during their official time for two to three hours followed their own personal works instead of processing the files of the applicants. In many cases the employees have been seen to be busy in their personal activities during official time.

Meanwhile, the other half of the respondents of this study said that they have not observed the employees of the land distribution process performing their personal work. In addition to these two different views, an answer that can be drawn from the observation and evaluation done by the VCA Unit indicates that informal activities whether less or more can damage and make the process vulnerable with the passage of time. Some of the points noted by the respondents are those that are common in all organizations and are reasons behind why the people complain about the quality of services provided by governmental entities.

From the views expressed by respondents and information obtained through the observations and analysis of the VCA Unit, it can be concluded that informal activities do exist in the land distribution process which is one of the factors contributing to the vulnerability of the process. Also, some employees working for the process spend time on personal issues during official time.

\section{iv. Management and control of staff performance}

Respondents with positive remarks presented the example of some employees of the directorate who have been referred to judicial and prosecuting authorities and said the step indicated the presence of internal control. Conversely, respondents with negative views about the question said that laws and regulations are broken on a daily basis as the employees are not bound to time and they delay their work, demand gifts and have conflicts of interest and other such issues. According to them, the presence of such problems is evidence of the lack of adequate control in the concerned organization.

Internal control and management have key roles in the effective implementation of laws and regulations and also in giving a practical shape to a process. Therefore, internal control and management are one of the standards for us based on which vulnerabilities caused by corruption can be identified. Whether there are enough internal control and management arrangements for the effective implementation of the land distribution process of the Directorate of Refugees Affairs in Kabul is a question to which most of the interviewees gave negative responses.

In response to this question, the interviewees said that the level of internal control and management in the Directorate of Refugees Affairs in Kabul, especially in the land distribution process, was not adequate. They believed that if internal control and management were adequately practiced in the implementation of the law and land distribution process and there had been effective monitoring of employee activities, the applicants would not have as many complaints as they have now. 
One of the respondents said, "There is no internal control and management, as there should be." Also there is no penalty and fine system. Most of the times, the employees including the senior officials of the Kabul Refugees Affairs directorate are not present at their work place. Therefore, applicants' problems have increased as the concerned employees remain absent, delay works and do not take interest in their jobs. This indicates a lack of sufficient internal control.

At the same time, some other respondents confirmed the issue in their interviews and talked of the incompetence of senior officials of the Refugees Affairs Directorate in Kabul. In their views, if the senior officials of this directorate were competent and qualified, the land distribution process would improve and would be implemented in an effective manner. One of the interviewees said, "If the senior officials of this directorate had the willingness and intention to implement law in this organization, the people would not lose trust in it."

Without going through the details, responses and information included in the questionnaire show that internal control and management is insufficient. The lack of adequate internal control and management is one of the factors that have resulted in the vulnerability of the land distribution process of the Directorate of Refugees Affairs and caused the people not to trust this organization.

\section{v. Informal assignment of privileges and responsibilities}

In this section, the meaning of informal salaries and assignment of duties and responsibilities can be interpreted as an employee's payment in a way that has no basis in the organization's laws, procedures, job descriptions or other regulations. Do informal salary payments and informal assignment of duties and responsibilities exist? In response to this question, the interviewees said that only the informal assignment of duties and responsibilities existed in the directorate. In their belief, the employees working for the land distribution process have repeatedly performed activities that are not included in their job descriptions just because their superior instructs them to do so. According to the interviewees, the last article in the job descriptions of the employees can be misused for various purposes. Generally, the last article of their job descriptions reads as such:

Perform other related tasks that are assigned and are in accordance with laws and regulations

Additionally, some of the other respondents say that the informal assignment of duties to employees sometimes takes place through senior officials of the Refugees Affairs directorate of Kabul province. One of the respondents said in the questionnaire, "some of the senior officials of the Refugees Affairs directorate in Kabul province own companies that operate in the refugee housing scheme. Sometimes for their own personal interest, they compel the employees to perform tasks for their own company rather than official work."

In short, from all the information and responses of the interviewees, it can be concluded that the informal payment of salaries and assignment of informal responsibilities do exist. But assigning 
informal duties to employees is considered more serious since such practices have been repeatedly proven and observed.

\section{vi. Undue influence}

Those who believed that the process was under unreasonable influence openly expressed their views about interference from MPs and direct phone calls from ministers, deputy ministers, politically strong people and land mafias to the officials of the land distribution process. Interviewees gave examples of how such people entered the concerned offices for diverting the process towards the interest of certain people. On the other side, the applicants also confirmed this problem. Even some of the employees suggested to applicants to contact any MPs or authorities they know so that their application can be processed in a better way. Applicants must have backup from a strong political figure, if they want their work to be processed quickly. Such a trend has turned into a common part of the process. Those who disagreed with the existence of such kind of trends did not present any reason or logic for their views.

Unreasonable influence can be defined as a situation in which external and internal factors exert illegal pressure during the implementation of the process to divert it towards their own personal interests and objectives. Is the land distribution process impacted by unreasonable influence? The majority of the interviewees gave positive replies. A majority of the interviewees of this research believed that unreasonable influence and illegal pressures are exerted on the land distribution process by high government authorities, MPs, land mafias and other politically strong people. According to them, this condition exists in the process more than one's expects.

Certain land mafias try to create obstacles for the land distribution process when they see things go against their interest. Certain high government authorities including MPs and ministers also play a role in exerting such pressure. They have been repeatedly observed trying to allocate land for their relatives and friends who do not deserve it.

According to some of the interviewees, illegal pressure is exerted on the employees of the land distribution process, but they resist and do not surrender to this pressure. One of the respondents, who is also an employee of the process says, "unreasonable influence and illegal pressure are common in the process, but the employees of the directorate neglect the pressure and act according to the commitment they have made." However, a significant number of respondents considered unreasonable influence and illegal pressure as one of the factors that have resulted in vulnerabilities of the land distribution process. It can be concluded that unreasonable influence diverts the process from its legal and actual destination more than any other factor.

Based on the information that has been directly obtained from the applicants, employees and even high officials of the directorate and from close observation of the proceedings of the process, it can be concluded that unreasonable influence is undoubtedly exerted on the employees of the process by various people including government authorities, MPs, members of provincial councils and other influential people.

\section{vii. Improper variation of the process}

A majority of the interviewees were of the belief that land mafia groups and influential people created obstacles for the Directorate of Refugees Affairs and did not allow the directorate to 
allocate shelter or land to repatriates smoothly. They demand their shares in the refugee housing schemes. Most of the respondents who had a positive opinion to the question also accused the people who meddle in the land distribution process of improperly diverting it towards their own interest. Such a trend, according to respondents, is an injustice to the rights of deserving repatriates.

This question highly resembles the previous one when it comes to its purpose and objective. It was put in front of the interviewees for the purpose of more clarification of the issue it covers. Whether efforts are expended to improperly divert the activities of the land distribution process is a question to which the interviewees gave a positive response.

The interviewees of this research said that much effort is made from certain people to direct the land distribution process towards their own interests. According to them, some high authorities of MoRR try to divert the land distribution process. This issue has various and numerous examples. One of the signs of the issue is the fact that certain individuals and groups threaten the employees of the process.

Another example of this issue is the illegal occupation of plots located near the refugee housing schemes by a certain group that claims to be the real owner of the land. Such groups are no one else other than land mafias. Additionally, one of the respondents who had been allocated land in the refugee housing scheme said, "some people who are actually related to the land mafias call themselves local residents and hinder the process of land distribution. They create obstacles for the process and demand a $25 \%$ ownership of land in refugee housing schemes. Some of the employees of the Directorate of Refugees Affairs are also involved in supporting such people."

In short, from the findings and responses of the interviewees, it can be concluded that much effort is made to interfere in and direct the land distribution process towards an improper direction. Even some senior officials of the Kabul Refugees Affairs Directorate are accused of such acts. Therefore, this issue is one of the factors that has damaged the land distribution process and made it vulnerable. For addressing the problem the recommendations in a later part of the report should be taken seriously and measures should be in place to implement them.

\section{viii. Gifts}

The interviewees, who were also applicants, noted that not only the employees demand gifts but also receive bribes quite openly. They said that they have witnessed three applicants who gifted dresses and dry fruit to a high-ranking member of the Directorate of Refugees Affairs. Generally, giving gifts after one receives the land is inevitable. Interviewees who said such practice was not common among the employees were actually employees themselves. According to them, demanding gifts and bribes is against the law and avoided discussing the issue any further.

An absolute majority of the interviewees expressed a positive response to the question, "do employees demand gifts for performing an activity that is actually their duty?" The reasons for this, according to the respondents, are the low salaries of the employees, the lack of internal control and management and the lack of a penalty and fine system. 
Low salaries and other reasons mentioned above are not the only reasons why the employees demand gifts. The problem is caused by various factors that need more space to be explained here. In addition, the respondents also blame the high authorities of the concerned organization for demanding gifts to perform their activities. One of the interviewees said, "just now, one of the applicants gifted dry fruit and cosmetics to one senior official of the Kabul Refugees Affairs Directorate. This is a sample example. Unfortunately, there are many huge examples that become visible after one pays a little more attention."

Keeping in view the details in the questionnaire, the direct observation of the VCA Team and information from other sources, it can be summarized that demanding gifts from applicants has turned into a common practice in the land distribution process. This issue includes various levels of the organization and no level is an exception. Therefore, the concerns of the applicants are numerous about this aspect of the process.

\section{ix. Staff awareness of corruption}

In the discussion on the issue, the interviewees talked of the guidelines provided and management courses held by MoRR and the Independent Administrative Reform and Civil Service Commission. Also, some of the respondents shed light on the importance of workshops for the concerned employees on corruption, ethics and how to professionally treat the applicants.

In the belief of the interviewees, MoRR and its Directorate for Refugees Affairs in Kabul have not given awareness to the employees on the mentioned issues. According to a number of respondents, because some of the high authorities of MoRR lack efficiency, they did not allow other organizations that wanted to conduct short-term training workshops for boosting awareness of the MoRR employees. A minor portion of the respondents, however, maintain that the concerned employees are instructed about corruption and how to better deal with the applicants by the senior officials and other authorities but in an informal and improper way. Nonetheless, the kind of awareness-raising emphasized in the question (i.e. formal and planned training sessions conducted by MoRR or any other organization) has not taken place.

From the study and evaluation of the findings and obtained information, it can be concluded that MoRR and its Directorate for Refugees Affairs have not undertaken any programs aimed at creating awareness about the mentioned issues among the employees working for the land distribution process. The absence or low level of awareness about corruption and ways of dealing with applicants in a proper manner has negatively impacted the directorate, especially the employees working in the land distribution process.

\section{x. Job security}

Views expressed by the respondents were based on the fact that when it comes to the working protection of employees, the concerned laws are not obeyed. They emphasized that the issue needed to be addressed through the implementation of a comprehensive plan.

The interviewees stated that protection and safety for the civil servants (this includes employees of the land distribution process) for the activities they are asked to perform have been included in the Civil Service Law of Afghanistan. 
In summary, based on the information collected from various sources - especially from the responses of the interviewees - it can be concluded that protection for employees against the formal tasks that they have to perform have been included in the Civil Service Law of Afghanistan. If the mentioned law could be implemented efficiently, there would be no problem in regards to employee protection.

\section{xi. Conflicts of interest}

In the section where the interviewees can present their response to the question in detail, they considered the presence of conflicts of interest as one of the most serious challenges in the organization that can hinder the quality of construction works in the refugee housing schemes.

From the views expressed by the interviewees, it can be concluded that conflicts of interest do exist in the land distribution process, examples of which are the owning of personal construction companies by high-ranking officials of MoRR who force the people to award these companies construction work of the houses. Such officials are also involved in giving jobs to their relatives.

\section{xii. Vulnerabilities to corruption}

The VCA Unit pointed out the land distribution corruption opportunities through composing questions with contents such as: informal activities, management and control, inappropriate distribution of salaries, duties and responsibilities, unjustified influence, incorrect direction of obligations, receiving tips to do their jobs, awareness of staff members of this department about corruption, immoral and unprofessional behavior, immunity of staff members, and conflicts of interest within the work process and identified the following vulnerable points to corruption:

- Lack of enough coordination among ministries and responsible organs mentioned in Presidential Decree 104 caused bluntness and delayed the implementation of infrastructure and development projects in refugee housing schemes and land distribution to deserved applicants. In addition, this is the main factor in discouraging repatriates to settle in residential towns of refugees.

- The working procedure of the land distribution process is long, bureaucratic and complicated and contains 63 steps resulting in confusion of the applicants of the land distribution process. In addition, the land distribution process is organized illogically based on the stipulations of Presidential Decree 104, which are not applicable on the ground.

- The direct relation of the employees with the applicants on one hand has paved the way for corruption and on the other hand resulted in serious obstacles and various interferences in performance.

- Absenteeism and personal engagements of the employees during work hours and a lack of proper control and management of the Directorate of Refugees Affairs in Kabul has resulted in an overload of work, little attention given to the applicants, and the dissatisfaction of applicants of the land distribution process. 
- Unreasonable influence by different groups near residential towns, land mafias, MPs, members of provincial councils and members of the land distribution commission is seen in the process, which leads to injustice and corruption.

- Unprofessional behavior of employees and insisting that applicants pay bribes have been identified based on observations during the interviews. Even the physical assault of applicants by guards of the high officials of the Kabul Directorate of Refugees Affairs as per their instructions has been stated by interviewees.

- At least 3,500 shelters in refugees' housing schemes have been distributed to more than one deserving applicant in Kabul province which has caused conflicts among recipients.

xiii. Recommendations

a. The ministries and organs mentioned in Presidential Decree 104 involved in the process should assess and identify the factors causing delays in the implementation of infrastructure and development projects in refugees' residential towns and accelerate the implementation process of the mentioned projects in 60 distributed housing schemes in the country.

- Responsible entity: Director and members of the CCLD

- Deadline: 2 months after the issuance of the report

b. MoRR should develop and sign multilateral agreements with involved entities mentioned in Presidential Decree 104 and ensure the coordination of all efforts related to the affairs of the refugees' housing schemes.

- Responsible entity: MoRR

- Deadline: 2 months after the issuance of the report

c. The extra and unnecessary stages and steps of the process such as going to the Population Registration Office, getting the approval of district representatives and possessing a VRF should be simplified.

- Responsible entity: Director of the CCLD, Directorate of Resettlement and the administrative and legal advisors of MoRR

- Deadline: 3 months after the issuance of the report

d. The system should be changed into a one-stop-shop and the contact and connection of referrers with staff members should be cut in order to accelerate the land distribution process to deserving applicants and prevent the possibility for corruption.

- Responsible entity: Director of Central Commission, Provincial Commissions of Land Distribution Process, Directorate of Resettlement and Directorate of Refugees Affairs in Kabul

- Deadline: 3 months after the issuance of the report 
e. A mechanism regarding all interfering parties in governmental affairs should be developed to hamper the interference of MPs, ministers, and influential people in the affairs of administrations and directorates by, among other things, naming them.

- Responsible entity: MoRR in coordination with the CCLD

- Deadline: 1 month after the issuance of the report

f. The Attorney General's Office, Supreme Audit Office and the High Office of Oversight should jointly investigate the distribution of 3,500 shelters in refugees' housing schemes in Kabul province that were repeatedly distributed to more than one deserving applicant. In addition, the mentioned entities should admit to the similar events in the past and advocate for justice and the rights of the deserving applicants.

- Responsible entity: High Office of Oversight, Attorney General's Office and Supreme Audit Office

- Deadline: 45 days after the issuance of the report

\section{Information Management in the Land Distribution Process}

This is the fourth area that is evaluated in this research. The efficiency of an organization's service delivery to a major extent depends on how properly the document and information system of the organization works. If an organization applies traditional and classic methods in the preparation of its archive and management of its documents, its service delivery will be negatively impacted. Conversely, the presence of a modern and efficient document and information management system has a key role in the successful functioning of all parts of an organization, especially in the delivery of services and efficiency of its human resources.

The objective of analyzing this area of the land distribution process is the identification of challenges and problems in it that could result in a vulnerability of the process to corruption. For the identification of damages from this area and whether the damages can lead to corruption, certain questions were prepared to know the views of the interviewees.
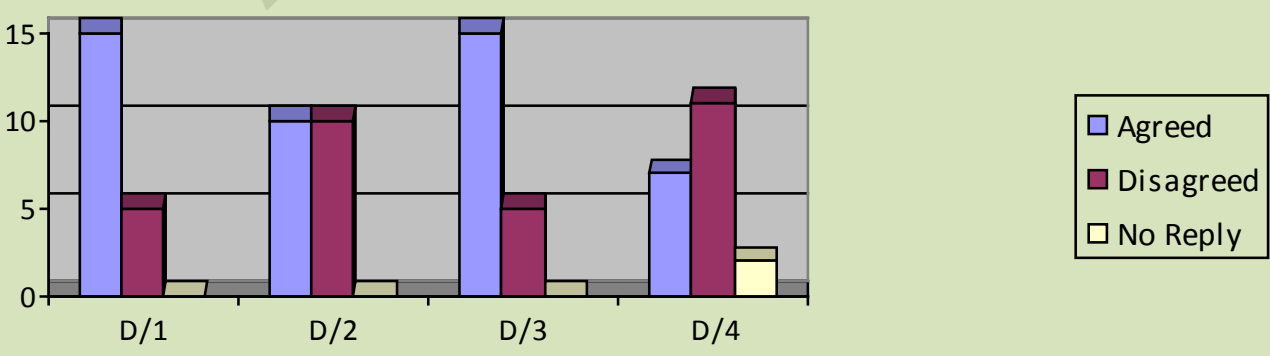

Figure 4: Responses to questions $D / 1$ to $D / 4$

\section{i. Current practices}

Interviewees said that obtaining documents or adding/removing information in their files took a lot of time and such tasks were at the discretion of the employees. According to them, if the employees want, the required information or document will be available in a short time. 
However, interviewees who expressed positive views actually confirmed the existence of a database system for the process. There is no doubt that the database system is merely used to store information, but besides that, the employees also file documents according to the classic (old) system.

The existence of a standard and favorable filing system in an organization not only creates ease for its employees but also facilitates service delivery and prevents the wastage of time. Such a condition would automatically result in the satisfaction of the people towards the organization. What is the condition in the Directorate of Refugees Affairs in Kabul? A majority of the interviewees said that the filing system and archive of MoRR, especially the Directorate of Refugees Affairs in Kabul, was old and classic.

In the views of the respondents, all the documents of the applicants are improperly kept in cupboards in the directorate that makes finding a specific file or document a troublesome task. The respondents, however, do not reject the work done so far in this regard. They say in the year 2005 a portion of the applicants' files were computerized and entered in the database system but it is not adequate and problems remain numerous.

A majority of the interviewees of this research say that the document and information management system in the concerned units working on the land distribution process is traditional and classic and in many cases creates problems for the applicants. Keeping that in view, it can be said that the lack of a standard system for the management of documents and information is one of the factors that has resulted in a vulnerability of the service delivery process of the Directorate of Refugees Affairs. Therefore, the problem needs urgent attention.

\section{ii. The existence of a system for information management}

Views expressed by the interviewees in this regard in the questionnaire are based on the fact that apparently both a database and traditional filing are used to maintain documents. The way these mechanisms are used results in corruption as the employees can misuse the mechanisms in many ways.

"Does your document and information management system have a clear mechanism to allow applicants to obtain any document they need?" In response to this question, participants of this research, a majority of whom are employees of the Directorate of Refugees Affairs, said that the archive or filing system of the units working on the land distribution process do not have any clear and responsive mechanism for this purpose.

Respondents were of the view that there is no clear mechanism defined to allow the applicants to obtain certain documents through an easy and simple procedure. Also, a lack of procedures and guidelines in this regard has caused dissatisfaction among the applicants. Some of the respondents said that the document and management system not only lacks a clear mechanism but also in some cases the applicants have to search for the documents on their own. One of them said, "sometimes the applicants themselves search for the documents in the cupboards of the concerned unit."

Therefore, the lack of a clear mechanism that allows applicants to have access to their documents is one of challenges that negatively impact service deliveryin the land distribution process. In addition to this, the respondents also talked about another issue. They said, "the 
document and information management system of this organization does not have an arrangement for the protection of documents." According to some of the respondents, the employees responsible for the maintenance of documents intentionally bring changes in the documents to make them deficient. In such a way they try to make an excuse for their inefficiency.

Keeping in view the information obtained from various sources, it can be said that the most vulnerable area in the document and information management system is when the completed applications are put in the boxes to be submitted to the land distribution commission. Apparently, this is the proper way to treat the applications, but from another point of view, there is a risk that one can change the turn of his application by bribing the concerned employees. Additionally, the employees do not pay the required attention to the applications despite the existence of a database system. Such a condition is either because of the inefficiency of the employees or because they face challenges due to the lack of a proper document and information management system. In general, based on the observation of the VCA Unit, it can be said that the document and information system of the land distribution process still faces a double challenge - not all of the information is recorded in the database and a majority of the employees do not know how to use and access the database.

\section{iii. Time intensiveness of the system}

In the belief of a number of interviewees, the document and information management system of the process is not the reason that causes delays in accessing documents and information, but the sincerity and sympathy of the employees. There have been cases where the documents of a certain applicant have not been found in a period of three months and also cases where documents have been made available urgently within two hours.

Keeping in view the above mentioned two issues - first, the lack of a standard and favorable filing system and second, the lack of a clear mechanism for allowing the applicants to access their documents - obtaining a document from the filing and archive system requires much time which can be identified as a vulnerable point in the process. A majority of the interviewees agree that obtaining a certain document from the archive needs much time.

The interviewees say that when the document and information management system is maintained in an old and classic way and there are no mechanisms or guidelines for accessing the documents, then obtaining a document would definitely consume a lot of time. One of the interviewees in response to the above question said, "the documents of an applicant had been lost in the directorate. Whenever he came to the concerned office to obtain his document, he would be asked to come a month later. Finally, his documents were found after one year by his own effort."

From the views expressed by the interviewees, it can be said that until the document and information management system of the units concerned with the land distribution process is computerized in a standard and favorable way and a proper mechanism and guidelines for obtaining documents are in place, the problems that arise from this area will remain unresolved. According to the respondents, until the two issues stated above are addressed, obtaining a document will continue to consume much time. 


\section{iv. Information security}

In general, the views of the interviewees were based on the point that the documents of the applicants are not protected and that there are even opportunities for others to change the contents of the documents. A number of the respondents believe that the employees intentionally change the information in the documents to make them deficient. In such a way, they try to conceal their inefficiency and poor performance.

Keeping in view the information obtained from respondents, the direct observation of members of the VCA Unit and the views of the employees and applicants, it unfortunately seems as if the level of protection of the documents is not sufficient and they are vulnerable up to an extent that employees can change their contents and information. On the other hand, if the applicants require access to their documents, they have to face a number of problems as the process is quite complicated. From the tone of the interviewees, it can be judged that they do not believe that their documents are protected and kept confidential. They fear that their completed document might go missing one day.

It can be concluded that the current document and information management system does not provide the required level of secrecy and protection for the documents.

\section{v. Vulnerabilities to corruption}

In spite of the existence of a database system at the ministry, it seems that the employees of the process are not using it properly and still keeping the documents in a disorganized manner. This has resulted in clients losing documents.

Due to the ability of employees to improperly put case files at the front of the processing queue, those who are without recommenders often have to wait for many years until their turn arrives or to pay a bribe to the employees.

Due to the unprofessional behavior of the process employees, access to documents and information is time consuming which results in various types of corruption, including negligence in performing their duties and requests for bribes.

\section{vi. Recommendations}

a. The access of employees to change the order of applications should be limited and controlled. A daily electronic reporting mechanism should be established in the document and information management system of the process.

- Responsible entity: Secretariat of the CCLD, Directorate of Resettlement and Central Database Section

- Deadline: 2 months after the issuance of the report

b. A mechanism regarding all interfering parties in governmental affairs should be developed to hamper the interference of MPs, ministers, and influential people in the affairs of administrations and directorates by, among other things, naming them.

- Responsible entity: Provincial Directorates and Central Database Section

- Deadline: 2 months after the issuance of the report 


\section{Annex}

\begin{tabular}{|c|c|c|}
\hline No. & Stages and steps of the land distribution process & $\begin{array}{l}\text { Responsible } \\
\text { person/office }\end{array}$ \\
\hline \multicolumn{3}{|c|}{ Stage 1: Submission of Application and Identity Check } \\
\hline 1 & $\begin{array}{l}\text { Preparation and submission of application along with tazkira and } \\
\text { VRF to MoRR or its directorate in the concerned province }\end{array}$ & Applicant \\
\hline 2 & $\begin{array}{l}\text { Review of application and referral to the concerned directorate for } \\
\text { further processing }\end{array}$ & Minister \\
\hline 3 & Registration of minister's instruction and the concerned file & $\begin{array}{l}\text { Document and } \\
\text { Relation } \\
\text { Management Unit }\end{array}$ \\
\hline 4 & Dispatch instruction to the concerned directorate. & $\begin{array}{l}\text { Applicant/Document } \\
\text { and Relation } \\
\text { Management Unit }\end{array}$ \\
\hline 5 & $\begin{array}{l}\text { Refer the instruction for further process to Housing Management } \\
\text { Unit }\end{array}$ & $\begin{array}{l}\text { Chief of Staff's } \\
\text { Office }\end{array}$ \\
\hline 6 & $\begin{array}{l}\text { Prepare a request letter to the Population Registration Office for a } \\
\text { confirmation of applicant's tazkira }\end{array}$ & $\begin{array}{l}\text { Housing and IDPs } \\
\text { Management Unit }\end{array}$ \\
\hline 7 & Sign and stamp the request letter & Chief of Staff \\
\hline 8 & Record the letter in dispatch register of housing management unit & $\begin{array}{l}\text { Concerned } \\
\text { employee of } \\
\text { Housing and IDPs } \\
\text { Management Unit }\end{array}$ \\
\hline 9 & $\begin{array}{l}\text { Review by Head of the Population Registration Office and referral to } \\
\text { concerned unit for formal processing }\end{array}$ & $\begin{array}{l}\text { Head of the } \\
\text { Population } \\
\text { Registration Office }\end{array}$ \\
\hline 10 & Review and preparation of a request letter to the concerned district & Concerned Unit \\
\hline 11 & Sign and stamp the request letter to the concerned district & $\begin{array}{l}\text { Head of the } \\
\text { Population } \\
\text { Registration Unit }\end{array}$ \\
\hline 12 & $\begin{array}{l}\text { Review by General Management Unit of district and referral to the } \\
\text { official responsible for composing reply to the request letter }\end{array}$ & Concerned official \\
\hline 13 & $\begin{array}{l}\text { Preparation of reply for the request letter and signature by head of } \\
\text { the concerned unit }\end{array}$ & $\begin{array}{l}\text { Head of concerned } \\
\text { unit in the district }\end{array}$ \\
\hline 14 & $\begin{array}{l}\text { Signature by Head of Population Registration Office of the } \\
\text { respective district }\end{array}$ & $\begin{array}{l}\text { Head of Population } \\
\text { Registration Office }\end{array}$ \\
\hline 15 & $\begin{array}{l}\text { Transfer reply of the request letter to the directorate for further } \\
\text { processing }\end{array}$ & Applicant \\
\hline \multicolumn{3}{|c|}{ Stage 2: Proof for repatriation or internal displacement } \\
\hline 16 & $\begin{array}{l}\text { Preparation of request letter to the office of the concerned district to } \\
\text { obtain information regarding residency and repatriation of the } \\
\text { applicant. This is done by the Housing and IDPs Management Unit }\end{array}$ & $\begin{array}{l}\text { Housing and IDPs } \\
\text { Management Unit }\end{array}$ \\
\hline 17 & Get signature and stamp of the Director of Refugees Affairs & $\begin{array}{l}\text { Chief of Staff of } \\
\text { Directorate of } \\
\text { Refugees Affairs } \\
\end{array}$ \\
\hline 18 & $\begin{array}{l}\text { Take the letter to district/area representative for confirming current } \\
\text { residency and repatriation of the applicant }\end{array}$ & Applicant \\
\hline 19 & $\begin{array}{l}\text { Confirmation of applicant's current residency and repatriation by } \\
\text { district/area representative }\end{array}$ & $\begin{array}{l}\text { District/area } \\
\text { representative }\end{array}$ \\
\hline 20 & $\begin{array}{l}\text { Confirmation of applicant's residency and repatriation by concerned } \\
\text { office of the concerned district in Kabul/Province }\end{array}$ & $\begin{array}{l}\text { Concerned Unit of } \\
\text { the District }\end{array}$ \\
\hline
\end{tabular}




\begin{tabular}{|c|c|c|}
\hline 21 & $\begin{array}{l}\text { Get signature and stamp of district head based on the confirmation } \\
\text { from district/area representative }\end{array}$ & District Head \\
\hline 22 & Record and register the confirmation & $\begin{array}{l}\text { Employee tasked } \\
\text { with entry and } \\
\text { dispatch of letters } \\
\end{array}$ \\
\hline 23 & $\begin{array}{l}\text { Return reply to the request letter to Housing and IDPs Management } \\
\text { Unit }\end{array}$ & Applicant \\
\hline 24 & $\begin{array}{l}\text { The Unit rejects the application if: (1) The reply to the request letter } \\
\text { is negative from both the Population Registration Office and office } \\
\text { of the concerned district in Kabul/province. (2) If the identity of the } \\
\text { applicant is confirmed but not his residency and repatriation/internal } \\
\text { displacement. The unit retains the document. } \\
\text { In case there is a negative reply to the request letter for } \\
\text { confirmation of the applicant's identity and his repatriation by the } \\
\text { office of the concerned district in Kabul/province, the documents of } \\
\text { the applicant will be officially referred to the Directorate of Refugees } \\
\text { Affairs in the concerned province. }\end{array}$ & $\begin{array}{l}\text { Housing and IDPs } \\
\text { Management Unit }\end{array}$ \\
\hline \multicolumn{3}{|c|}{ Stage 3: Record and register - deserving or non-deserving applicant } \\
\hline 25 & $\begin{array}{l}\text { If there is a positive reply to the request letter from both the } \\
\text { Population Registration Office and concerned district, the Housing } \\
\text { and IDPs Management Unit will register the application for further } \\
\text { processing. }\end{array}$ & $\begin{array}{l}\text { Housing and IDPs } \\
\text { Management Unit }\end{array}$ \\
\hline 26 & $\begin{array}{l}\text { Housing and IDPs Management Unit hands the form specified for } \\
\text { people who have no shelter to the applicant to fill it in. Then the } \\
\text { form is recorded in a register }\end{array}$ & $\begin{array}{l}\text { Housing and IDPs } \\
\text { Management Unit }\end{array}$ \\
\hline 27 & $\begin{array}{l}\text { The applicant fills the form correctly and completely and certifies the } \\
\text { information in it }\end{array}$ & Applicant \\
\hline 28 & $\begin{array}{l}\text { The applicant takes the form to the district/area representative or } \\
\text { tribal elder of the concerned district or area }\end{array}$ & Applicant \\
\hline 29 & $\begin{array}{l}\text { The district/area representative or the tribal elder certifies that the } \\
\text { applicant does or does not have shelter/land }\end{array}$ & $\begin{array}{l}\text { District/area } \\
\text { representative or } \\
\text { tribal elder }\end{array}$ \\
\hline 30 & $\begin{array}{l}\text { The applicant takes the form to the office of the concerned district in } \\
\text { Kabul/province to certify whether the district/area representative or } \\
\text { tribal elder is authorized }\end{array}$ & Applicant \\
\hline 31 & $\begin{array}{l}\text { Office of the concerned district in Kabul/province confirms that the } \\
\text { district/area representative is authorized }\end{array}$ & District Head \\
\hline 32 & $\begin{array}{l}\text { The applicant submits the form to the Housing and IDPs } \\
\text { Management Unit for further processing }\end{array}$ & Applicant \\
\hline 33 & $\begin{array}{l}\text { Housing and IDPs Management Unit will reject the application if it } \\
\text { has not been certified that repatriate has no shelter. Otherwise, the } \\
\text { case will be forwarded for ranking, recording and registration in the } \\
\text { database unit. }\end{array}$ & $\begin{array}{l}\text { Housing and IDPs } \\
\text { Management Unit }\end{array}$ \\
\hline 34 & $\begin{array}{l}\text { The database unit will record, register, and number the form and } \\
\text { will send it to the Housing and IDPs Management Unit }\end{array}$ & Database unit \\
\hline 35 & $\begin{array}{l}\text { Housing and IDPs Management Unit will prepare the document of } \\
\text { the repatriate for forwarding to the concerned commission. }\end{array}$ & $\begin{array}{l}\text { Housing and IDPs } \\
\text { Management Unit }\end{array}$ \\
\hline 36 & $\begin{array}{l}\text { Provincial Director of Refugees Affairs acts as secretary of the } \\
\text { commission to include applicant's documents in the agenda }\end{array}$ & $\begin{array}{l}\text { Director of Refugees } \\
\text { Affairs }\end{array}$ \\
\hline 37 & $\begin{array}{l}\text { Members of the commission will study and evaluate the applicant's } \\
\text { documents from a technical point of view }\end{array}$ & $\begin{array}{l}\text { Members of } \\
\text { Commission }\end{array}$ \\
\hline
\end{tabular}




\begin{tabular}{|c|c|c|}
\hline 38 & $\begin{array}{l}\text { The commission will send the documents to the Directorate of } \\
\text { Refugees Affairs if they have errors. If the documents are correct, } \\
\text { the applicant will be deemed eligible for land and the number and } \\
\text { address of the land will be included in the form. The commission will } \\
\text { sign the form. }\end{array}$ & $\begin{array}{l}\text { Members of } \\
\text { Commission }\end{array}$ \\
\hline 39 & $\begin{array}{l}\text { The Directorate of Refugees Affairs corrects the technical errors in } \\
\text { the document. The applicant may be called, if any additional } \\
\text { documents or information are required. The reviewed documents } \\
\text { will be resent to the commission. }\end{array}$ & $\begin{array}{l}\text { Director of Refugees } \\
\text { Affairs }\end{array}$ \\
\hline 40 & $\begin{array}{l}\text { The commission will once again review the documents. It will } \\
\text { endorse that the applicant deserves the land. The number and } \\
\text { address of the piece of land will be added to the form and the } \\
\text { commission will sign it. }\end{array}$ & $\begin{array}{l}\text { Land distribution } \\
\text { Commission }\end{array}$ \\
\hline 41 & $\begin{array}{l}\text { The documents will be sent to the Housing and IDPs Management } \\
\text { Unit for further processing }\end{array}$ & $\begin{array}{l}\text { Secretary of the } \\
\text { commission }\end{array}$ \\
\hline 42 & $\begin{array}{l}\text { The Housing and IDPs Management Unit will contact the deserving } \\
\text { repatriate }\end{array}$ & $\begin{array}{l}\text { Housing and IDPs } \\
\text { Management Unit }\end{array}$ \\
\hline \multicolumn{3}{|c|}{ Stage 4: Payment of the price of land and allocation of land to the deserving repatriate } \\
\hline 43 & $\begin{array}{l}\text { The Housing and IDPs Management Unit introduces the deserved } \\
\text { applicant to the Finance and Administration Unit through a formal } \\
\text { letter so that he can get the payment slip }\end{array}$ & $\begin{array}{l}\text { Housing and IDPs } \\
\text { Management Unit }\end{array}$ \\
\hline 44 & Register and dispatch the letter & $\begin{array}{l}\text { Employee } \\
\text { responsible for entry } \\
\text { and dispatch of } \\
\text { letters }\end{array}$ \\
\hline 45 & $\begin{array}{l}\text { Finance and Administration Unit refers the letter to accounting } \\
\text { officer }\end{array}$ & $\begin{array}{l}\text { Finance and } \\
\text { Administration Unit }\end{array}$ \\
\hline 46 & $\begin{array}{l}\text { The accounting officer hands the letter to the unit's employee } \\
\text { responsible for the entry and dispatch of letters to enter it in the } \\
\text { register }\end{array}$ & $\begin{array}{l}\text { Accounting officer } \\
\text { and Dispatcher }\end{array}$ \\
\hline 47 & $\begin{array}{l}\text { The accounting officer prepares the payment slip and hands it to } \\
\text { the Finance and Administration Unit for signature }\end{array}$ & Accounting officer \\
\hline 48 & $\begin{array}{l}\text { Finance and Administration Unit signs and hands the letter to the } \\
\text { deserved applicant }\end{array}$ & $\begin{array}{l}\text { Finance and } \\
\text { Administration Unit }\end{array}$ \\
\hline 49 & $\begin{array}{l}\text { The approved applicant takes the payment slip to Da Afghanistan } \\
\text { Bank, pays the money and gets a bank payment receipt }\end{array}$ & Approved applicant \\
\hline 50 & $\begin{array}{l}\text { The approved applicant takes the receipt to the Housing and IDPs } \\
\text { Management Unit }\end{array}$ & Approved applicant \\
\hline 51 & $\begin{array}{l}\text { The Housing and IDPs Management Unit takes a formal } \\
\text { commitment from the approved applicant that he will build a house } \\
\text { on the land within a specified time }\end{array}$ & $\begin{array}{l}\text { Housing and IDPs } \\
\text { Management Unit }\end{array}$ \\
\hline 52 & $\begin{array}{l}\text { The Housing and IDPs Management Unit introduces the approved } \\
\text { applicant to the engineer of the refugee housing scheme } \\
\text { responsible for handing over the plot to him }\end{array}$ & $\begin{array}{l}\text { Housing and IDPs } \\
\text { Management Unit }\end{array}$ \\
\hline 53 & The engineer marks the plot and hands it over to the repatriate & $\begin{array}{l}\text { Engineer for } \\
\text { Refugee housing } \\
\text { scheme }\end{array}$ \\
\hline \multicolumn{3}{|c|}{$\begin{array}{l}\text { Stage 5: Complete } 30-40 \% \text { of the construction work and receive the temporary document by } \\
\text { the approved applicant }\end{array}$} \\
\hline 54 & $\begin{array}{l}\text { The repatriate is responsible for completing } 30 \text { percent of the } \\
\text { construction work on his land within three months. The responsible } \\
\text { engineers will monitor this work }\end{array}$ & Approved applicant \\
\hline 55 & $\begin{array}{l}\text { The approved applicant gathers all the documents and submits } \\
\text { them to the Housing and IDPs Management Unit }\end{array}$ & Approved applicant \\
\hline
\end{tabular}




\begin{tabular}{|c|c|c|}
\hline 56 & $\begin{array}{l}\text { The Housing and IDPs Management Unit ensures that all the } \\
\text { documents are present for issuing the temporary ownership } \\
\text { document to the repatriate }\end{array}$ & $\begin{array}{l}\text { Housing and IDPs } \\
\text { Management Unit }\end{array}$ \\
\hline 57 & $\begin{array}{l}\text { If the documents are complete, the Housing and IDPs Management } \\
\text { Unit will once again take commitment from the repatriate that he will } \\
\text { complete the remaining } 70 \% \text { of construction work within one year }\end{array}$ & $\begin{array}{l}\text { Housing and IDPs } \\
\text { Management Unit }\end{array}$ \\
\hline 58 & $\begin{array}{l}\text { Record and register the commitment letter after the repatriate signs } \\
\text { it }\end{array}$ & $\begin{array}{l}\text { Housing and IDPs } \\
\text { Management Unit }\end{array}$ \\
\hline 59 & $\begin{array}{l}\text { The Housing and IDPs Management Unit prepares the temporary } \\
\text { ownership document in the name of the repatriate and the head } \\
\text { signs it }\end{array}$ & $\begin{array}{l}\text { Housing and IDPs } \\
\text { Management Unit }\end{array}$ \\
\hline 60 & $\begin{array}{l}\text { The Director of Refugees Affairs will sign the document based on } \\
\text { the signatures of the head of the Housing and IDPs Management } \\
\text { Unit }\end{array}$ & $\begin{array}{l}\text { Director of Refugees } \\
\text { Affairs }\end{array}$ \\
\hline 61 & $\begin{array}{l}\text { Head of the concerned commission will also sign the document } \\
\text { based on the signature of the Director of Refugees Affairs }\end{array}$ & Head of Commission \\
\hline 62 & $\begin{array}{l}\text { When the document is signed, it is recorded and registered by the } \\
\text { responsible employees in the Housing and IDPs Management Unit }\end{array}$ & $\begin{array}{l}\text { Housing and IDPs } \\
\text { Management Unit }\end{array}$ \\
\hline 63 & $\begin{array}{l}\text { The temporary ownership document is handed over to the } \\
\text { deserving repatriate }\end{array}$ & $\begin{array}{l}\text { Housing and IDPs } \\
\text { Management Unit }\end{array}$ \\
\hline
\end{tabular}

